\title{
Approaches Employed by Teachers in Teaching Literature to Less Proficient Students in Form 1 and Form 2
}

\author{
Radzuwan Ab. Rashid (Corresponding author) \\ Faculty of Education, Universiti Teknologi Mara (UiTM) \\ Section 17 Campus, 40200 Shah Alam, Selangor, Malaysia \\ Tel: 60-13-599-9313 E-mail: andy_hakim85@yahoo.com \\ Malachi Edwin Vethamani \\ School of Education, Languages and Communications \\ Wawasan Open University \\ Tel: 60-3-9281-7323Ｅ-mail: malachiev@wou.edu.my
}

Shireena Basree Abdul Rahman

Faculty of Education

Universiti Teknologi Mara (UiTM)

Section 17 Campus, 40200 Shah Alam, Selangor, Malaysia

Tel: 60-3-5522-7423 E-mail: shire417@salam.uitm.edu.my

\begin{abstract}
This study aimed to identify the approaches and strategies employed by teachers in teaching the literature component to less proficient students in Forms 1 and 2 in selected secondary schools in Kelantan, Malaysia. The study was conducted in 18 rural schools. Triangulation involving the questionnaire as the primary data and classroom observation and semi-structured interview as the secondary data was used. Findings show that the information-based approach is popularly employed by teachers, followed by moral-philosophical approach and paraphrastic approach. The findings indicate that the teaching approach is influenced by the students' inability to comprehend English language which forces teachers to spoon feed the students and use the students' mother tongue as the medium of instruction. The implication is that literature teaching with the aims of developing students' language and thinking skills and generating students' personal response and appreciation may not be achieved.
\end{abstract}

Keywords: Approaches in teaching literature, Less proficient students

\section{Introduction}

Ten years ago, the literature component was incorporated in the English Language syllabus with the main aim of enhancing students' language proficiency. The incorporation of the literature component had initially mixed response from teachers, parents and students. The responses from teachers and students have become more positive with its full implementation (Vethamani (2007). For students with some and high English language proficiency, the literature component was a welcome as it added a dimension of enjoyment to their learning while developing their language skills. This is because "the reading of literary texts involves the development of complex skills and tools of inquiry and these skills and tools maybe interpreted to include the gathering of information related to an issue or problem, an analysis of personal values as they relate to the issue or problem, reflecting upon various options for solution, and selecting and applying the most appropriate option" (Ganakumaran 2007: 1).

In contrast, the incorporation of the literature component into the English Language syllabus was definitely not welcomed by students with low English language proficiency as they did not have the complex skills needed to read literary texts. Even without the incorporation of the literature component into the syllabus, these students were already struggling learning the language and the incorporation of the literature component was seen as adding another burden. Tina Abdullah, Hassan Zakaria, Fauziah Ismail, Fara Adlina, and Marzilah (2007) found that many teachers claimed that the language level of the literary texts selected by the Ministry was difficult for many students to comprehend. With limited vocabulary and a lack of competence in language skills, the literature component, became a challenge for many students. 
The present study focuses on less proficient students and how they cope with their literature lessons. The study will focus on the approaches and strategies employed in the teaching of the literature component in English to the less proficient group to examine if these approaches help to meet the aims of incorporating the literature component into the English language paper.

\subsection{Purpose of the study}

This study aims to gain a general overview of the approaches and strategies employed by teachers in teaching literature to less proficient students in Form 1 and Form 2. The research questions for this study are as follows:

1) What are the approaches employed by teachers in teaching literature to the less proficient group?

2) What are the strategies used by teachers based on the approaches employed?

3) Why do teachers employ such approaches?

4) What are the teachers' perceptions on the teaching of literature to less proficient students?

5) How do these students react to the approaches employed by teachers?

6) What are the students' feedback on the approaches and strategies employed by their teachers?

\section{Review of literature}

This review of related literature explains briefly the general aims of teaching literature. It also discusses the three models to teaching literature and elaborates on the approaches to the teaching of literature.

\subsection{General aims of teaching literature}

The learning objectives of literature component outlined by the Curriculum Development Centre cited by Cheng (2007) are as follows:

1) To instill and inculcate the reading habit among pupils.

2) To enrich pupils' vocabulary and language content.

3) To enhance pupils' thinking skills.

4) To promote cultural understanding in the Malaysian context.

5) To improve English language proficiency of pupils.

6) To provide lively, enjoyable and high-interest readings.

Although it is not stated in the list above, it is argued that literature is also taught for aesthetic appreciation. This is discernible through a closer look at the learning outcomes stated by the Ministry of Education where the students should be able to discuss about the characters, plot, setting, author's point of view and other literary elements found in the text (Ganakumaran 2003). Among the aims of incorporating literature in English into the English language programme according to Vethamani (2004:57) was "to help students improve their language skills (especially reading) and also to experience both education and pleasure when reading literary texts.

Below are some reasons for the incorporation of literature in language education.

\subsubsection{Inculcating reading habits among pupils:}

Calia (2009) suggests that parents can develop literary interest in children by reading to them in the initial phases of their lives. She further argues that encouraging them to read daily will expose them to language and reinforce the importance of reading. However, teachers seem to carry this responsibility in Malaysia. With the incorporation of the literature component into English syllabus, the responsibility to develop reading habits through literature lays heavily on teachers. In a historical overview of Literature Programs in Malaysia by Ganakumaran (2003) reveals that the literature was used in school through English language reading programs since 1976. These programs were primarily aimed at using literary materials to increase learner's exposure to English both inside and outside classroom. There were two reading programs conducted for secondary schools namely English Language Reading Program (ELRP) and Class Reader Program (CRP) where the latter was developed to replace the former (Vethamani 1993). However, both ELRP and CRP failed to contribute to the development of English Language standard in the country as these programs were not tested in exam and many teachers did not have required skills in approaching the literary texts (Ganakumaran 2003). Therefore, it is hoped that the incorporation of literature component as a tested part in English language syllabus will help raise the standard of English among Malaysian students.

\subsubsection{Enriching pupils vocabulary and language content}

Reading literary texts definitely offers opportunities for students to come across many words. Basnett and Grundy (1999) cited by Mario Sarceni (2003) claim that literature is learnt because of its powerful language which marks the 
greatest skills a language user can demonstrate. Chan (1999) further argues that literature is illustrative of different genres, text-types, register, narrative structures, point of view, patterning of words and sounds. According to Maley (2001) cited by Mario Sarceni (2003), the text may also be used as an example of certain types of pattern and structure.

\subsubsection{Enhancing pupils' thinking skills}

Tierney and Pearson (1983) cited by Collins (1993) posit that readers will use their prior knowledge to interpret meanings. The process of linking the prior knowledge to what is being read develops higher level thinking skills in students. Collins (1993) further argues that in order for a learner to achieve the higher level of reading, he/she must be able to relate new information to what is known in order to find answers to cognitive questions. Besides that, the nature of a literary text which could be interpreted in many ways could be used to develop thinking skills (Mario Sarceni, 2003).

\subsubsection{Promoting cultural understanding}

Valdes (1986:137) cited by Plastina (2000) claims that literature is a medium to "transmit the culture of the people who speak the language in which it is written". Thus, the ideas and values presented in literature are much influenced by the history, culture and circumstances relevant to the individuals who produce them. Langer (1991) cited by Tina Abdullah et al. (2007) claims that the teaching of literature is often considered "a way to indoctrinate students into the cultural knowledge, good taste and high culture of the society". To promote cultural understanding in Malaysian context, Ministry of Education has introduced short stories such as 'The Pencil' by Ali Majod, 'How Dalat Got Its Name' by Heidi Munan, and 'Of Bunga Telur and Bally Shoes' by Che Husna Azhari and also poems like 'Monsoon History' by Shirley Lim and K.S. Maninam's novel, 'The Return'in the first cycle of literary texts used in this programme. In the second cycle, this is done through the poems 'Heir Conditioning' by $\mathrm{M}$ SHANmughalingam and 'A Fighter's Lines' by Marzuki Ali.

\subsubsection{Improving English language proficiency}

Collie and Slater (1987), Oster (1989), Lazar (1993) and Vethamani (2004) all agree on the notion that literature can be used to enhance students' main language skills especially reading and writing. According to Collie and Slater (1987), by reading a specific text, students are exposed to the formation and function of sentences, the diversity of possible structures and the different ways of linking ideas. All these will expand and deepen students' writing skills. In addition to that, oral work based on literary texts may help improve students' speaking skills (Mario Saraceni, 2003). Lazar (1993) further argues that students can develop their listening skills by listening to the recorded literary materials.

\subsubsection{Providing lively, enjoyable and high-interest readings}

Brumfit and Carter (1986) state that "there is interaction involves between the reader and the literary texts as the texts provide examples of language resources being used to the full and the reader is placed in an active interactional role in working with and making sense of this language". According to Collie and Slater (1987), this interaction can be a source of enjoyment for the students. Maley and Duff (1994) further argue that literature can make people respond personally to other people's way of seeing things and can engage both their intellect and their emotion.

The teaching of literature can be generally seen through the three models presented by Carter and Long (1991).

\subsection{Models to teaching literature}

Carter and Long (1991) state there are three models of teaching literature:

1) The Cultural Model which is a traditional approach of teaching literature where learners need to discover and infer the social, political, literary and historical context of a specific text. It reveals the universality of thoughts and ideas and learners are encouraged to understand different cultures and ideologies in relation to their own. This model views literature as a source of facts and it is teacher centered where the teacher passes knowledge and information to the students.

2) The Language Model which is an approach that offers learners an opportunity to access a text in a systematic and methodical way. This approach allows teachers to apply strategies used in language teaching such as cloze procedure, prediction exercises, jumbled sentences, summary writing, creative writing and role play to deconstruct literary texts in order to serve specific linguistic goals. Savvidou (2004) asserts that students engage with the text purely for linguistic practice and literature is used mechanistically to provide a series of language activities.

3) The Personal Growth Model which is an approach that focus on the personal development of the students including emotions and personal characteristics. It requires students to relate and respond to the themes and issues 
by connecting them to their personal life experiences. It is influenced by both cultural model and the language model where the focus is on the particular use of language in a text in a specific cultural context.

These models for teaching literature have been incorporated in various approaches, as shown below.

\subsection{Approaches in teaching literature}

The three models discussed above denote different approaches. What is then an approach? An approach, according to Anthony (1963), was "a set of assumptions dealing with the nature of language, learning and teaching". Brown (2001) defines approach as "theoretically well-informed positions and beliefs about the nature of language, the nature of language learning and the applicability of both to pedagogical settings". Moody (1983) cited by Diana Hwang \& Amin Embi (2007) explains that the importance of an approach is to "provide a framework, or sequence of operations to be used when we come to actualities". Based on the definitions above, it is clear that an approach will influence teaching strategies. There are many approaches that can be employed to teach literature to below average group such as the information-based approach, language-based approach, personal response approach, paraphrastic approach and moral-philosophical approach. Stylistic approach is excluded in this research as learners require a degree of language competence even before they participate in learning using the approach and therefore it is more likely to cater for intermediate and advance learners and not applicable for less proficient group.

\subsubsection{Language-based approach}

This approach is closely related to the Language Model presented by Carter and Long (1991) where literary texts are seen as means to helping students' improve language proficiency. This is done by providing them exposure to the target language and connecting them to specific vocabulary and other aspects of the language. A. Maley and Duff (1990) insist that the primary aim of this approach is "quite simply to use literary texts as a resource for stimulating language activities". With the use of language-based approaches, the focus shifted to the learner, the reading process and creating language awareness in the learners (Too Wei Keong 2007). In line with this approach, a language-based framework for reading literary texts is proposed by McRae (1991) and McRae and Vethamani (1999) which moves from lexis (vocabulary), syntax (sentences) to coherence (discourse). It also focuses on phonology (sounds), graphology (visual effect of the text), semantics (meaning), dialect (variations of standard English), register (tone), period (archaisms) and function (message in the text).

\subsubsection{Paraphrastic approach}

This approach deals with the surface meaning of the text (Diana Hwang \& Amin Embi 2007). Rosli (1995) asserts that it allows teachers to use simpler words and sentence structures compared to the more complicated ones in the texts and sometimes the teacher can translate it into other languages. He argued further that this approach is suitable for beginners of the target language as it acts as a stepping stone in formulating original assumptions of the author's work.

\subsubsection{Information-based approach}

This is an approach that demands a large input from the teacher and it is closely related to the term Literature with a big ' $L$ ' proposed by McRae (1991). It describes the study of literature as "aesthetically patterned artifact endowed with the knowledge potentials philosophy, culture, morality, and humanities" (Ganakumaran 2007:2). Carter and Long (1991) further argue that it involves critical concepts, literary conventions and metalanguage and the students should be able to use such terms and concepts in talking and writing about literature. This approach is a way of teaching knowledge about literature where literature is seen as a medium to offer a source of information to students (Carter 1988).

\subsubsection{Personal-response approach}

This approach is associated with Personal Growth Model proposed by Carter and Long (1991) as it aims is to elicit personal response and foster students' personal development. Hirvela (1996) argues that this approach focuses on learner's response to the author's text. The learners would respond to what they think are the author's intentions and what are the meanings that could be derived from the text. Vethamani (2003) further argues that although learners are encouraged to explore various textual meanings, their interpretation must be in tandem with the text. Rosli (1995) claims that this approach motivates and encourages students to read by making a connection between the themes of the texts studied and their personal life experiences.

\section{2..3.5. Moral-philosophical approach}

This is an approach which incorporates moral values across curriculum. The focus of this approach is to discover moral values while reading a particular literary text (Diana Hwang \& Amin Embi 2007). It seeks to find the worthiness of moral and philosophical considerations behind one's reading (Rosli 1995). Ministry of Education has 
outlined 17 moral values to be inculcated among secondary school students such as being independent, being honest, being grateful, and respecting others.

\section{Methodology}

\subsection{Research design}

The present study utilized both quantitative and qualitative methodologies. It used a mode of triangulation whereby data collection and information were based on a questionnaire as the primary instrument, and classroom observation and semi-structured interview as secondary instruments.

\subsection{Location of the Study}

The study was conducted in 18 secondary schools from rural areas in Kelantan.

\subsection{Sample}

There were two targeted groups in this research. The first group was English Language teachers who taught less-proficient group in Form 1 and Form 2. Among these teachers, ten teachers (5 taught Form 1 and another 5 taught Form 2) were selected randomly to be observed and interviewed. The second targeted group was the less-proficient students. The determination of the less-proficient group was based on the band score for School Based Oral Assessment (SBOA) and writing test outlined by Ministry of Education. For the purpose of this paper, less-proficient students were those who scored below Satisfied Band for both the SBOA and writing test. Among these students, fifty were selected randomly to be interviewed. They were ten from each school (5 Form 1 students and 5 Form 2 students).

\subsection{Research Instruments}

For the purpose of primary data collection, two sets of questionnaires were designed. The first questionnaire was distributed to the teachers who teach English to less-proficient group in Form 1 and Form 2. This questionnaire consisted of Yes-No items. Another set of questionnaire was distributed to the students of the teacher who had been observed to get their feedback on the approaches and strategies employed by the teacher. This questionnaire consisted of Yes-No items followed by 'why' question items and one open-ended question item to allow respondents to express their opinion and suggestions on matters related to the research topic.

A classroom observation checklist, adapted from Banerjee (1995) was used. The checklist had seven columns which documented sequence of activity, time spent for each activity, what the teacher does, what the students do, type of interactions between the teacher and the students, and skills practised. The checklist was then summarized, compared and interpreted in order to indentify the main approach and strategies used by each teacher as well as patterns of reactions and responses from their students.

The interview questions for teachers were categorized and coded into a few constructs, namely profile of teachers (Q1), teachers' views on the teaching of literature to less proficient students (Q2), teaching approaches and strategies employed (Q3), factors that influence teachers' selection of approaches and strategies (Q5) and students' reactions to the approach and strategies used (Q6). The interviews were audio taped, transcribed and interpreted. The interview questions for students were also categorized and coded into a few constructs, namely profile of students (Q1), their feelings towards the approach employed by their teachers (Q2), their evaluation on the effectiveness of the approach employed (Q3) and their suggestions on how literature should be taught in class (Q4).

\subsection{Data Analysis and Procedures}

The study required quantitative and qualitative data analysis. Descriptive statistical analysis was used for the quantitative data. Classroom observation field notes were compiled. Each observation was summarized and compared in order to draw appropriate conclusions and interpretations. The interview transcripts were grouped, coded and verbatim from the transcripts and were quoted to strengthen the basis of argument.

\section{Findings}

\subsection{Demographic profile of teachers}

A total of 92 teachers responded to the questionnaire at a return rate of $76 \%$. Table 1 reports the breakdown of respondents according to the respective aspects namely gender, academic qualification, area of specialization (teaching option), levels taught, experience in teaching English as well as training in the teaching of the literature in English component. (Table 1)

\subsection{Approaches employed by teachers and strategies employed by teachers}

The findings of the questionnaire (see Table 2) revealed the information-based approach (mean $=6.57$ ) is the most favoured approach among teachers. This is followed by the moral-philosophical approach $($ mean $=6.52)$, paraphrastic approach $($ mean $=5.57)$, and the personal-response approach $($ mean $=4.65)$. The least employed is 
language-based approach (mean = 4.57). Findings also concur with item no.17 "explain the main content of the text to the class" (see Table 3 ) which has the highest mean score (mean $=3.0)$. A significant $91.3 \%(\mathrm{n}=84)$ of respondents reported that they explain the main content of the text to the class. This is followed by item number 12 which has the second highest mean score $($ mean $=2.9)$. A prominent $85 \%(\mathrm{n}=78)$ of respondents stated that they "ask questions to check students' knowledge based on what they have read". This item sets the third highest mean score $($ mean $=2.9)$. $($ Table 2$)$

\subsection{Strategies Employed for Each Approach for Teaching of literature}

(Table 3)

\subsection{Why teachers employ such approaches?}

From the data through the interviews it is discernible that teachers had their own justifications for their choice of strategies and approaches to teaching literature in their classrooms. All of them agreed that information-based approach most suit their students' level. However, they did employ moral-philosophical and paraphrastic approach to add variety in their teaching styles.

\subsubsection{Information-based approach}

Even though all the teachers preferred to employ this approach, they differed in their medium of instruction and strategies. Sixty three percent of the teachers interviewed chose to explain the main content of the text to the class in students' mother tongue. Another 37\% code-switched during the lessons. The teachers read the texts aloud in English but the explanation were totally done in students' mother tongue and most of the times they translated the texts word by word. Among their reasons were:

“...to ensure they have deeper understanding...they are weak...” [ITA/Q4]

“...I must translate it to their mother tongue as most of them don't understand even a word in the text..." [ITC/Q4]

“...Even they are in form 1 a form 2, I've to use their mother tongue to prepare them for the exam. At least when they understand the text, they can guess the answers..." [ITD/Q4]

Among those who tried to use English as medium of instruction, they used pictures and body gestures to help students comprehend what they were explaining. The reasons were:

“...My students enjoy drawing. When I asked them to do something they like, they seem to understand things better..." [ITF/Q4]

“...they laugh when I show body gestures. That makes them less tense and more open to say few words in English..." [ITH/Q4]

\subsubsection{Moral-philosophical approach}

As determined by the interviews, this approach was employed as a complement to information -based approach. Among the reasons given by the teachers were:

"I only used the approach when I feel like the questions about moral value will come out in exam..." [ITB/Q4]

"For me, when my students have known and remembered all the important information in the story, I'll switch to moral-philosophical approach. It's important as the Ministry of Education always emphasizes the 'moral value across curriculum, ". [ITG/Q4]

"My first task is to ensure the students understand the story well. When they got it, I'll stress the moral value found in the story so that they are aware of it. Hopefully, it helps them to become a good person" [ITI/Q4]

\subsubsection{Paraphrastic approach}

Among the reasons given by the teachers who employed this approach were:

"I tried not to teach in bahasa. I used simple English. Very simple English. That will expose them to the language." [ITF/Q4]

"This is a second language class. There is no point for the students to be here if the teacher keeps teaching in bahasa. I will stick to this paraphrastic approach even though it is tiring to paraphrase almost all sentences in the story for these less proficient students. Let them understand English even tough it is time consuming." [ITH/Q4]

\subsection{Teachers' views on the teaching of literature to less proficient students}

Teachers seem to have different views on the teaching of literature to less proficient students. Among all the respondents interviewed, $38 \%$ had positive views and another $62 \%$ seemed to have negative views on the teaching of literature to less proficient students. 


\subsubsection{Positive views}

Those who had positive views claimed that they believe on the potential of literature in helping less proficient students to develop their language. However, they emphasized that teachers really need to play their roles in giving proper guidance to the students. Among their reactions were:

"It is interesting to teach literature to them but we have to guide them very well. If they

don't understand the text, they can't respond to us and that makes our lesson not interesting at all..." [ITE/Q1]

"It's an excellent idea. It's important. Literature helps students improve their English. My students love story especially the graphic novel like Black Beauty. I believe they have potential to be pushed to understand English" [ITF/Q1]

“...good idea but needs good methods. Student could be helped through literature but they need to be guided properly. [ITF/Q1]

4.5.2. Less positive views

Teachers who did not have positive views on the teaching of literature to less proficient students found that it was a difficult task to do. That was mainly related to students' proficiency level which affected the flow of teaching and learning process. Among their reactions were:

“...difficult to teach...students don't understand the words...students can't enjoy the lesson...We should start with something simple and related to students. The Pearl for example is very difficult. It's set in Mexico. Not in local context" [ITA/Q1]

“...simplification of the texts is needed. It's so hard for less proficient students. I was wondering how to make literature lesson interesting. Even for the second cycle of the texts, I myself don't really understand the texts yet." $[\mathrm{ITB} / \mathrm{Q} 1]$

“...difficult...It's a real challenge for teachers. Literature is too foreign for the students. How can they learn when they never read at the first place?" [ITH/Q1]

\subsection{Students' reactions and responses to the approaches employed by teachers}

Based on the classroom observation, there was the same pattern in the reactions of the students regardless of different approaches used by their teachers. They were the passive listeners who jotted down what the teachers asked them to jot down. They did not respond when the teachers asked questions to the whole class. The only response given was when the teacher pointed out questions to certain individuals. Even though the questions were asked in simple English, they asked further clarification in their mother tongue. The answers given were one word answers which were done in their mother tongue.

\subsubsection{Classroom observation of Teacher D}

In Teacher D's class, when the teacher was giving input on theme, students listened quietly. When asked to state one of the themes they ever heard, they responded in their mother tongue giving one word "persahabatan" which means friendship. When the teacher moved to the worksheet, the students started to look up the meanings of the words in dictionary and discussed with their friends in their mother tongue even though Teacher D instructed them to do it individually. The lesson ended up with Teacher D gave all the answers to the students.

\subsubsection{Classroom observation of Teacher $F$}

Even in Teacher F's class who claimed that the students were more active in classroom when drawing activities were included in the lesson, the students actually were still passive. They were excited to draw but when the teacher asked them to explain their drawing, they were not able to do so. When encouraged by the teachers, only two students had the gut to stand up and said few words about the drawing and even that was done in their mother tongue.

\subsubsection{Classroom observation of Teacher $\mathrm{G}$}

A different scenario was observed in Teacher G's class. She was teaching Chapter Two in Potato People. Her students were also less proficient students but they were better compared to the students in the classroom observed earlier since they could comprehend simple English. Thus, most of the time, Teacher G used English as medium of instruction. She started the lesson by recalling what had been learned during the previous lesson and asked students to relate what they had learned earlier to themselves. The second phase of the lesson was answering literal questions. 
She read the questions orally and the students needed to skim and scan the text to find the answers. Among the questions were:

"What did Mr. Graystone do?"

"For how many years people of Skullgoragh do not pay their rent?"

"What is Skullgoragh?" [CO2TG]

In this class, the students were actively involved in the lesson. Even Teacher $\mathrm{G}$ asked them to write the answers in the exercise book, they managed to say out the answers verbally a few seconds after the teacher finished reading the questions. Teacher $\mathrm{G}$ then finished the second phase of the lesson by discussing the answers as a whole class activity. She then continued by writing the summary of Chapter Two of the novel before ending the lesson with a piece of advice for the students to comprehend this chapter thoroughly. The pattern of Teacher G's lesson can be summarized as follow: (Figure 1)

\subsubsection{Classroom observation of Teacher $\mathrm{H}$}

Another enjoyable scenario was observed in Teacher $\mathrm{H}$ class who used body gestures to teach the theme of the poem The River by Valerie Bloom. This was a very weak class that students could not understand even simple English and the medium of instruction was totally their mother tongue. The teacher began with explaining what is the poem about stanza by stanza then went on to read the poem aloud. Students were asked to read after the teacher. The teacher then assigned each stanza to each group and asked the students to transform what was written in the stanza into body movements. The students came up with creative movements to represent the river as a wanderer, a winder, a hoarder, a baby, a singer and a monster. Teacher $\mathrm{H}$ then continued by focusing on the last stanza which is negatively connotated and wrote down the theme of the poem on white board. The structure of Teacher $\mathrm{H}$ class can be summarized as follow: (Figure 2)

\subsection{Students' feedback on the approaches and strategies employed by teachers}

Table 4 displays the frequency and percentage of students' feedback on the approaches and strategies employed by the teachers whilst Table 5 listed the activities and lessons suggested by the students to be included in their literature classes. The findings indicate that students do have positive feedback on the approaches and strategies employed by their teachers. A significant $85 \%(n=196)$ respondents reported that they like the way their teachers teach literature. Finding also revealed that the drama activity is the most favoured activity (mean $=4.5)$ followed by the quiz activity $($ mean $=4.2)$ and the speaking activity / lesson $($ mean $=2.7)$

(Table 4)

(Table 5)

\section{Discussion}

The analysis of the data from the questionnaire and the classroom observation reveals the current teaching scenario in rural secondary schools in Kelantan. Interestingly, the five approaches for teaching literature have been employed at a moderate to high level in the literature lessons. The information based approach and moral philosophical approach were among the most favoured approaches in the literature classroom. The findings do not reflect a concomitant setting to earlier study conducted by Diana Hwang and Amin Embi (2007) whose findings manifested that the paraphrastic approach was the most favoured approach in the literature classroom.

The difference is perhaps mainly due to the different sample of study. Diana Hwang and Amin Embi (2007) did not focus on less proficient students in their study so it offers the opportunity for the teachers to use English as the medium of instruction when teaching intermediate and advanced level students and therefore they employed the paraphrastic approach in their explanations. In contrast, the present study focus on the less proficient students and through the classroom observation, it was observed that the teachers taught the students totally in their mother tongue so parapharstic approach was less employed in the literature classroom.

To some extent, information-based approach which was the most favoured approach by teachers in this study is appropriate as it ensures students gain enough information on the literary texts studied and thus develop their understanding on the subject matter. However, it becomes teacher-centered as the teacher explains, delineates and "spoon feeds" the students. This is probably not the best practice in the literature classroom. One of the objectives of learning literature outlined as by the Curriculum Development Centre is to enhance pupil's thinking skills and if the teachers keep providing the students all the necessary information, this objective will never be achieved. Worse, the teachers' use of students' mother tongue in giving and explaining the information to students will not help their students to develop their English language. Perhaps, that is why a large number of the respondents (students) in this 
study wanted speaking activities to be conducted in the literature classroom as they want to speak and practice their English.

The moral philosophical approach, the second most favoured approach to be employed in literature classroom connects well with the "moral value across curriculum" included in KBSM in order to develop more humanistic values. Since this study focuses on the less proficient students who usually lack of motivation to study, the teachers may have taken this path of incorporating moral values in the lesson.

In term of teachers' perspective on the teaching of literature to less proficient students, only a handful of respondents have positive views. This finding is indeed a matter of concern and their views will determine how they teach in the literature lessons. As seen in the classroom observations, only the teachers who have positive views on the teaching had attempted to be creative and develop fun activities in the lessons by incorporating drawing activities, bodily kinesthetic movements and other activities. Those who had negative views towards teaching literature had merely provided information to the students thus made the literature lessons less interesting and dull.

Despite having rather uninteresting literature lessons, the students still claimed that they liked their literature lessons. These lessons were however, not beneficial for the students and they gained very little from their lessons. The students often merely copied notes that were given to them without thinking or trying to present their own interpretations on what was read. There are two possible reasons why these less proficient students liked their literature lessons. The first, the "spoon feeding" lessons made it easy for them to pass examinations. Second, it has become part of their learning culture to say they like what they have to do in school. Ironically, the classroom observations did not indicate that these students enjoyed their literature lessons.

Since the students were expected to be the passive listeners, teachers did not conduct any interesting activities in the lessons. However, the findings reveal that the students want their teachers to conduct interesting activities in the lessons. Still, drama activities and quizzes were the most favoured activities to be included in the literature lessons by the students. Drama activities which require students to speak and move are favoured by the students. This is a big contrast to what is happening in the current literature lessons where they are expected to listen passively.

\section{Conclusion}

The incorporation of literature component in English into the English Language syllabus is not a recent phenomenon. Supposedly, after ten years in the syllabus, teachers should be able to teach literature effectively so that the objectives outlined by the Curriculum Development Centre can be achieved. Yet, the incorporation of the literature component is still argued and debated amongst teachers, students, researchers, parents as well as the policy makers. This study allows one to see and understand how the Literature Component in English is taught in rural schools. More prominently, it reveals the fact that the teachers who are at the front line of teaching face great difficulties in teaching literature to less proficient students. However, they have to adapt all the approaches and strategies to suit the needs of this group of students so that the aims and the objectives of the Literature Component in English will be attended to and hence, successfully accomplished and not a mere futile exercise.

\section{Referrences}

Anthony, E. M. (1963). Approach, method and technique. English Language Teaching, 17, 63-67.

Banerjee, A.C. (1995). Teaching Chemical Equilibrium and Thermodynamics in Undergraduate General Chemistry

Classes. Journal of Chemical Education, 72(10).

Brown, D. H. (2001). Teaching by principles: An interactive approach to language pedagogy. New York: Longman.

Brumfit, C. and Carter, R.A. (eds) (1986). Literature and Language Teaching. Oxford:Oxford University press.

Calia, B.A. (2009). Establishing Infant Reading Habits: Introducing Literature to Baby Boy. Suite101.com. [Online]

Available: http://infanttoddlerdevelopment.suite101.com/article.cfm/developing_the_male_reader (Jan 2, 2010).

Carter, R. and Long, M. (1991). Teaching literature. London: Longman.

Chan, P.K.W. (1999). Literature, Language Awareness and EFL. Language Awareness, 8(1), 38-50. Routledge.

Cheng. (2007). Issues in the Teaching and Learning of Children's Literature in Malaysia. K@ta, 9 (2). [Online] Available: http://puslit2.petra.ac.id/ejournal/index.php/ing/article/viewFile/16693/16685 (Feb 15, 2010).

Collie, J. and Slater, S. (1987). Literature in the Language Classroom. Cambridge: Cambridge University Press.

Collins, N.D. (1993). Teaching Critical Reading through Literature. Eric Digest. [Online] Available: http://www.ericdigests.org/1994/literature.htm (January 2, 2010). 
Ganakumaran, S. (2003). Literature programmes in Malaysian schools: A historical overview. In Ganakumaran, S. (ed). Teaching of literature in ESL/EFL contexts. Petaling Jaya: Sasbadi Sdn. Bhd., 27-48.

Hirvela, A. (1996). Reader-response theory and ELT. ELT Journal, 50(2), 127-134. Oxford: Oxford University Press.

Hwang, D and Embi, A. (2007). Approaches Employed by Secondary School Teachers to Teaching the Literature Component in English. Jurnal Pendidik dan Pendidikan, 22, 1-21, [Online] Available: myais.fsktm.um.edu.my/.../Approaches_Employed_By_Secondary_School_Teachers_To_Teachng_The_Literature Component_In_English.pdf (Feb 5, 2010).

Lazar, G. (1993). Literature and language teaching. Cambridge: Cambridge University Press.

Maley, A. and Duff, A. (1990). Literature. Oxford: Oxford University Press.

McRae, J. (1991). Literature with a small 1. Basingstoke: MEP Macmillan.

McRae, J. and Vethamani M.E. (1999). Now Read On. London: Routledge.

Ministry of Education of Malaysia. (1999). Curriculum specifications for the literature component in the English language curriculum for secondary schools. Kuala Lumpur: Ministry of Education of Malaysia.

Oster, J. (1989). Seeing with different eyes: Another View of Literature in the ESL Class. TESOL Quarterly, 23(1), 85-103.

Plastina, A.F. (2000). Teaching Culture in Literature in the ESL/EFL Classroom. The Internet TESL Journal, VI(3). [Online] Available: http://iteslj.org/Lessons/Plastina-CultureInLiterature/ (Jan 7, 2010).

Rosli Talif. (1995). Teaching literature in ESL the Malaysian context. Kuala Lumpur: Penerbit Universiti Pertanian Malaysia.

Sarceni, M. (2003). "Literature in the EFL Classroom: Roses or Thorns?". In Subramaniam, G. and Vethamani M.E. (Eds.) Teaching Literature in ESL/EFL Contexts. Petaling Jaya: Sasbadi Sdn. Bhd.

Savvidou. (2004). An Integrated Approach to Teaching Literature in the EFL Classroom. The Internet TESL Journal, Vol. X, No 12, [Online] Available: http://iteslj.org/Techniques/Savvidou-Literature.html (Feb 8, 2010).

Tina, A., Mohammad, H.Z., Fauziah, I., Fara, A. \& Marzilah, A.Z. (2007). A New Teaching Model to Teach Literature for the Tesl Pre-Training Service Programe in Universiti Teknologi Malaysia. [Online] Available: http://eprints.utm.my/3970/1/75167.pdf (Jan 10, 2010).

Too Wei Keong.(2007). "Language-Based Approach”. In Subramaniam, G. and Vethamani M.E. (Eds.) Approaches to Teaching Literature: Theory and Practice. Petaling Jaya: Sasbadi Sdn. Bhd.

Vethamani, M.E. (1993). The Teaching of Literature in English in Malaysian Schools. In Brumfitt, C. and Benton, M. (eds). Teaching Literature: A World Perspective. London: Modern English Publications and the British Council.

Vethamani, M.E. (2003). New Englishes New Literatures in English: Challenges for ELT Practitioners. In Ganakumaran, S. (ed). Teaching Literature in ESL and EFL Contexts. Petaling Jaya: Sasbadi Sdn. Bhd.

Vethamani, M.E. (2004). Changing Tides: Teaching Literature in English in Malaysian Secondary Schools. In David, M. K. (ed) Teaching of English in Second and Foreign Language Settings: Focus on Malaysia. Berlin: Peter Lang, 52-58.

Vethamani, M.E. (2007). The Ebb and Flow of English language Education in Malaysia. In Vethamani, M. E. and Perumal, R. (eds). Teaching English in Malaysia. Petaling Jaya: Sasbadi Sdn. Bhd., 1-10. 
Table 1. Demographic profile of respondents

\begin{tabular}{|c|c|c|c|}
\hline & Profile & Number & Percentage \\
\hline \multirow[t]{2}{*}{ Gender } & Male & 36 & 39.1 \\
\hline & Female & 56 & 60.9 \\
\hline \multicolumn{4}{|c|}{ Academic Qualifications } \\
\hline \multirow{5}{*}{ Option } & Diploma & 4 & 4.3 \\
\hline & First Degree & 84 & 91.4 \\
\hline & Masters & 4 & 4.3 \\
\hline & English & 64 & 69.6 \\
\hline & Non-English & 28 & 30.4 \\
\hline \multicolumn{4}{|c|}{ Level Taught } \\
\hline & Form 1 & 14 & 15.2 \\
\hline & Form 2 & 22 & 23.9 \\
\hline & Both Forms & 56 & 60.9 \\
\hline \multicolumn{4}{|c|}{ Teaching Experience in English } \\
\hline & Less than 5 years & 22 & 23.9 \\
\hline & $5-9$ years & 22 & 23.9 \\
\hline & More than 10 years & 48 & 52.2 \\
\hline \multicolumn{4}{|c|}{ Trained to teach the Literature Component } \\
\hline & Yes & 62 & 67.4 \\
\hline & No & 30 & 32.6 \\
\hline
\end{tabular}

Table 2. Mean of approaches employed in the teaching of literature

\begin{tabular}{lc}
\hline Approach & Mean \\
\hline Language-Based Approach & 4.57 \\
Paraphrastic Approach & 5.57 \\
Information-Based Approach & 6.57 \\
Personal-Response Approach & 4.65 \\
Moral-Philosophical Approach & 6.52 \\
\hline
\end{tabular}


Table 3. Frequency and Mean of Strategies Employed in the Teaching of literature.

\begin{tabular}{|c|c|c|}
\hline Item & Frequency & Mean \\
\hline \multicolumn{3}{|l|}{ Language-Based Approach } \\
\hline 1. Guide students to infer meanings from clues in the text & 68 & 2.4 \\
\hline Guide students to read between lines & 50 & 1.8 \\
\hline \multicolumn{3}{|l|}{ Asking students to make predictions about what will } \\
\hline Happen next at key points of a story & 36 & 1.3 \\
\hline Guide students to express opinion towards a text & 40 & 1.4 \\
\hline Set simple language activities in literature lesson & 64 & 2.3 \\
\hline Generate language practice using the text & 50 & 1.8 \\
\hline 7. Use literary texts solely for small ' 1 '. & 12 & 0.4 \\
\hline \multicolumn{3}{|l|}{ Paraphrastic Approach } \\
\hline $\begin{array}{l}\text { 8. Provide a written paraphrased version as a } \\
\text { complementary reading text }\end{array}$ & 66 & 2.4 \\
\hline 9. Teach solely using a paraphrased version of the text & 26 & 0.9 \\
\hline 10. Guide students to paraphrase the text & 30 & 1.1 \\
\hline $\begin{array}{l}\text { 11. Explain figurative and ambiguous language used in } \\
\text { simple words }\end{array}$ & 54 & 1.9 \\
\hline \multicolumn{3}{|l|}{ 12. Use simple terms to explain what the story is about } \\
\hline To students & 82 & 2.9 \\
\hline 13. Re-tell the text to students to help them understand & 76 & 2.7 \\
\hline \multicolumn{3}{|l|}{ Information-Based Approach } \\
\hline \multicolumn{3}{|l|}{ 14. Guide students to identify and read informative } \\
\hline Extracts in the story & 74 & 2.6 \\
\hline \multicolumn{3}{|l|}{ 15. Provide specific details about the literary elements } \\
\hline found in the text & 52 & 1.9 \\
\hline 16. Elicit information from students about the text & 38 & 1.4 \\
\hline 17. Explain the main content of the text to the class & 84 & 3.0 \\
\hline 18. Provide students with background information & 68 & 2.4 \\
\hline $\begin{array}{l}\text { 19. Ask questions to check students' knowledge based on } \\
\text { what they have read }\end{array}$ & 78 & 2.8 \\
\hline \multicolumn{3}{|l|}{ Personal Response Approach } \\
\hline \multicolumn{3}{|l|}{ 20. Guide students to relate the themes to personal } \\
\hline \multicolumn{3}{|l|}{ 21. Ask students to compare the text to any text they have } \\
\hline 22. Elicit students' response to a text & 40 & 1.4 \\
\hline \multicolumn{3}{|l|}{ 23. Encourage students to express feeling towards the } \\
\hline \multicolumn{3}{|l|}{ Moral-Philosophical Approach } \\
\hline 24. Incorporate moral values in the lessons & 74 & 2.6 \\
\hline 25. Tell students directly the moral values found in the text & 68 & 2.4 \\
\hline 26. Ask students the values they learn from the text & 60 & 2.1 \\
\hline 27. Guide students to search moral values from a text & 66 & 2.4 \\
\hline $\begin{array}{l}\text { 28. Raise students' awareness of values derived from the } \\
\text { text }\end{array}$ & 58 & 2.1 \\
\hline
\end{tabular}

Table 4. Frequency and Percentage of Students' Feedbacks

\begin{tabular}{|c|c|c|c|c|c|}
\hline \multicolumn{2}{|r|}{ Item } & \multicolumn{2}{|c|}{ Frequency } & \multicolumn{2}{|c|}{ Percentage } \\
\hline & & Yes & No & Yes & No \\
\hline 1. & Like the way my teacher teaches literature & 196 & 34 & 85 & 15 \\
\hline 2. & Literature lesson is interesting & 192 & 38 & 84 & 16 \\
\hline 3. & $\begin{array}{l}\text { The way my teacher teaches literature helps me to } \\
\text { understand the text well }\end{array}$ & 166 & 64 & 72 & 28 \\
\hline 4. & Literature lesson is easy to follow & 124 & 106 & 54 & 46 \\
\hline 5. & $\begin{array}{l}\text { The way my teacher teaches literature makes me } \\
\text { become more interested in learning literature }\end{array}$ & 170 & 60 & 74 & 26 \\
\hline
\end{tabular}


Table 5. Frequency and Mean of Activities/Lessons Suggested by Students to be Included in Literature Classes.

\begin{tabular}{clcc}
\hline Activities / Lessons & Frequency & Mean \\
\hline 1 & Drama & 74 & 4.5 \\
2 & Quiz & 72 & 4.2 \\
3 & Speaking & 46 & 2.7 \\
4 & Exam-based Questions & 28 & 1.6 \\
5 & Writing & 26 & 1.5 \\
6 & Games & 20 & 1.2 \\
7 & Group work & 18 & 1.1 \\
\hline 8 & Spelling & 18 & 1.1 \\
9 & Reading & 18 & 1.1 \\
10 & Drawing & 10 & 0.6 \\
11 & Choral speaking & 6 & 0.4 \\
12 & Singing & 6 & 0.4 \\
13 & Listening & 4 & 0.2 \\
14 & Moral value & 12 & 0.7 \\
15 & Portfolio & 2 & 0.1 \\
16 & Meeting the author, poet & 2 & 0.1 \\
17 & Story telling & 2 & 0.1 \\
\hline
\end{tabular}

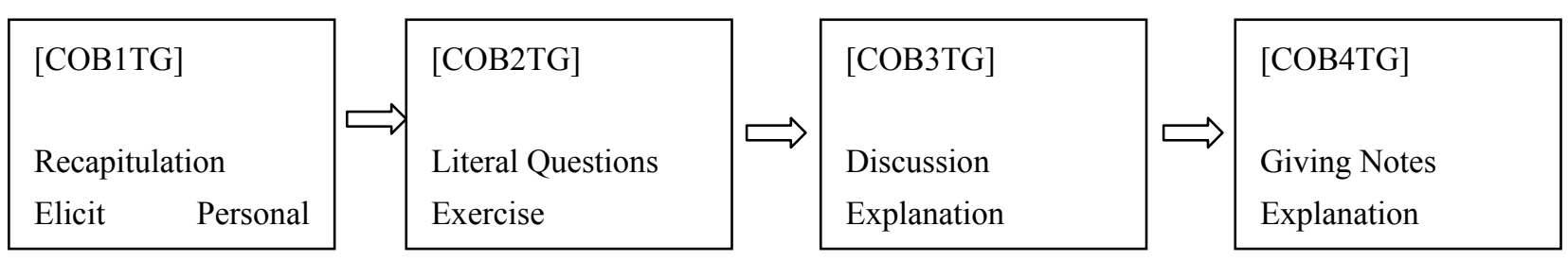

Figure 1. The pattern of Teacher G's lessons.

\begin{tabular}{|c|c|c|c|}
\hline [COB1TH] & [COB2TH $]$ & [COB3TH] & [COB3TH] \\
\hline Explanation & Bodily Kinesthetic & Explanation & Recapitulation \\
\hline
\end{tabular}

Figure 2. The pattern of Teacher H's lessons. 